\title{
Block them when it hurts
}

\author{
This article was published in the following Dove Press journal: \\ Local and Regional Anesthesia \\ 9 November 2015 \\ Number of times this article has been viewed
}

\section{Slagt \\ G) van Geffen}

Department of Anesthesiology, Pain and Palliative Care, Radboud University Medical Centre,

Nijmegen, the Netherlands
Correspondence: C Slagt

Department of Anesthesiology, Pain and Palliative Care, Radboud University

Medical Centre, PO Box 910I,

6500 HB Nijmegen, the Netherlands

$\mathrm{Tel}+3$ I 24 36| 4406

Email cor.slagt@radboudumc.nl

\section{Dear editor}

We read the article by Gadsden and Warlick with great interest. ${ }^{1}$ Good, patient-tailored pain relief is critical in all patients, but as stated by the authors, it is often suboptimal in trauma patients. Because of this, a trial was performed in collaboration with emergency medical service (EMS)-nurses in the South East Brabant Region, Eindhoven, the Netherlands. ${ }^{2}$ Patients with a proximal femur fracture are often difficult to transfer from the accident scene. Well-trained EMS-nurses performed a fascia iliaca compartment (FIC) block at the scene. Pain scores reduced by more than 50\%. Transfer dynamic pain scores were reduced to 3-4 (out of 10), with very high patient satisfaction scores. This study showed that FIC block is easy to learn and very effective. This form of regional anesthesia can be safely used at the accident site to improve patient comfort.

\section{Disclosure}

The authors report no conflicts of interest in this communication.

\section{References}

1. Gadsden J, Warlick A. Regional anesthesia for the trauma patient: improving patient outcomes. Local Reg Anesth. 2015;8:45-55.

2. Dochez E, van Geffen GJ, Bruhn J, Hoogerwerf N, van de Pas H, Scheffer G. Prehospital administered fascia iliaca compartment block by emergency medical service nurses, a feasibility study. Scand JTrauma Resusc Emerg Med. 2014;22:38. submit your manuscript | www.dovepress.com

Dovepress

http://dx.doi.org/10.2147/LRA.S95699 (c) (i) () 2015 Slagt and van Geffen. This work is published by Dove Medical Press Limited, and licensed under Creative Commons Attribution - Non Commercial (unported, v3.0) BY License. The full terms of the License are available at http://creativecommons.org/licenses/by-nd/3.0/. Non-commercial uses of the work are permitted without any further permision how to request permission may be found at: http://www.dovepress.com/permissions.php 
Dove Medical Press encourages responsible, free and frank academic debate. The content of the Local and Regional Anesthesia 'letters to the editor' section does not necessarily represent the views of Dove Medical Press, its officers, agents, employees, related entities or the Local and Regional Anesthesia editors. While all reasonable steps have been taken to confirm the content of each letter, Dove Medical Press accepts no liability in respect of the content of any letter, nor is it responsible for the content and accuracy of any letter to the editor.

Local and Regional Anesthesia

\section{Publish your work in this journal}

Local and Regional Anesthesia is an international, peer-reviewed, open access journal publishing on the development, pharmacology, delivery and targeting and clinical use of local and regional anesthetics and analgesics. The journal welcomes submitted papers covering original research, basic science, clinical studies, reviews \& evaluations,

guidelines, expert opinion and commentary, case reports and extended reports. The manuscript management system is completely online and includes a very quick and fair peer-review system, which is all easy to use. Visit http://www.dovepress.com/testimonials.php to read real quotes from published authors.

Submit your manuscript here: http://www.dovepress.com/local-and-regional-anesthesia-journal 